\title{
APLICAÇÃO DO ESTATUTO DA CIDADE EM SALVADOR: O DISCURSO E A PRÁTICA
}

\author{
THE APPLICATION OF THE CITY STATUTE IN SALVADOR: THE SPEECH AND THE PRACTICE
}

\author{
Célia Regina Sganzerla Santana ${ }^{2}$ \\ Edivaldo Machado Boaventura ${ }^{3}$
}

\begin{abstract}
Resumo
O artigo propõe uma visão crítica sobre a aplicação do Estatuto da Cidade (EC) em Salvador, uma década após sua aprovação. O trabalho se fundamenta em pesquisa documental sobre o processo de elaboração e revisão dos Planos Diretores de Desenvolvimento Urbano (PDDU) de 2004 e 2007, quando foram adotadas as propostas do EC, bem como em pesquisa de opinião com profissionais de diversos setores envolvidos naquele processo. O estudo busca compreender porque a maior parte das propostas do PDDU 2007 ficou no papel e o uso de alguns instrumentos urbanísticos tem se desviado dos princípios fundamentais do EC, contribuindo para gerar problemas de desvio de recursos públicos, corrupção e adensamento excessivo da cidade. O objetivo é discutir os limites e as possibilidades de aplicação do EC em Salvador, ao final da primeira década do século XXI, com vistas a reduzir as expectativas em relação ao poder do instrumento em si e, ao mesmo tempo, estimular a reflexão sobre novas formas de gestão da cidade.
\end{abstract}

Palavras-chave: Salvador, Estatuto da Cidade, PDDU

\begin{abstract}
The article takes a critical view on the implementation of the City Statute (EC) in Salvador, a decade after its approval. The work is based on documentary research on the process of preparing and reviewing the Urban Development Master Plans (PDDU) 2004 and 2007, when they were adopted the proposals of the EC, as well as survey with professionals from various sectors involved in that process. The study seeks to understand because most of the proposals of PDDU 2007 remained on paper and the use of some urban instruments has been diverted from the fundamental principles of the EC, helping to generate drift problems of public funds, corruption and excessive density of the city. The aim is to discuss the limits and possibilities of application of the EC in Salvador, the end of the first decade of this century, with a view to reducing the expectations of the power of the instrument itself and at the same time, encourage discussion of new forms of city management.
\end{abstract}

Keywords: Salvador, City Statute, urban development

\footnotetext{
1 Este artigo é parte do texto de dissertação da autora, produzido no âmbito do Programa de Pós-graduação em Desenvolvimento Regional e Urbano (PPDRU) da Universidade Salvador (Unifacs).

${ }^{2}$ Arquiteta e Urbanista, mestre em Desenvolvimento Regional e Urbano pela Universidade Salvador (PPDRU) e Gestora Pública Estadual. Atua na Diretoria de Estudos da Superintendência de Estudos Econômicos e Sociais da Bahia (SEI). E-mail: celiasganzerla@gmail.com.

${ }^{3}$ Doutor em Educação pela PennState University. Professor Emérito da Universidade Federal da Bahia (UFBA). Professor do Doutorado em Desenvolvimento Regional da UNIFACS. E-mail: edivaldoboaventura@gmail.com.
} 


\section{INTRODUÇÃO}

O Estatuto da Cidade (EC), Lei Federal 10.257/01, constituiu uma espécie de reação ao modelo de urbanização que vigorou (e de certo modo ainda vigora) no país até os anos setenta e que produziu uma espécie de divisão da cidade em parte bem servida (com serviços urbanos, infraestrutura e legalizada do ponto de vista urbanístico) e em parte relegada ao abandono, tanto pelo poder público quanto pelo mercado; e uma reação à visão tecnocrática de planejamento urbano, então predominante, cujas propostas para melhorar a cidade eram desconectadas do que efetivamente se praticava.

O Movimento Nacional pela Reforma Urbana (MNRU), não atingiu seus objetivos plenamente, mas, ao reconhecer o conflito urbano, teve o mérito de trazer para o campo político a questão social das cidades brasileiras. De acordo com sua concepção, o planejamento urbano deve buscar uma conciliação entre "cidade" e "não cidade", o que significa união entre as partes legal e ilegal, bem como entre planejamento e gestão da cidade, o que significa união entre as esferas técnica e política. O paradigma parte do pressuposto que "a cidade é produzida por uma multiplicidade de agentes que devem ter sua ação coordenada não em função de um modelo elaborado em escritórios, mas a partir de um pacto que corresponda ao interesse público" (CYMBALISTA, 2002).

Entretanto, os elementos técnicos, jurídicos e tributários que compõem o EC não são triviais e, uma década após a aprovação da lei, a aplicação destes instrumentos urbanístico-legais ainda constitui um imenso desafio para grande parte das cidades brasileiras. Em primeiro lugar, necessita-se da implantação de um moderno sistema de cadastro dos imóveis urbanos, que seja permanentemente atualizado, a cada nova autorização de ocupação, possibilitando o monitoramento constante. Exige-se também uma planta genérica de valores imobiliários, inexistente nas cidades do país. Desse modo, a falta de controle eleva o risco da utilização dos instrumentos para o aumento de receitas públicas, a manipulação política e os favorecimentos pessoais.

Para Maricato (2008), as dificuldades relacionadas à aplicação de instrumentos do EC, a exemplo do IPTU progressivo no tempo, revelam o primado absoluto da propriedade privada sobre o interesse público no Brasil.

Por outro lado, em relação à regularização fundiária houve progressos, particularmente nos anos 1990. Programas massivos de regularização são hoje fortemente apoiados por agências multilaterais, como o Banco Mundial. Entretanto, mesmo em favelas urbanizadas, são poucos os processos que completaram integralmente o ciclo, rompendo, sob o ponto de vista urbanístico e 
legal, a linha demarcatória que os separa da cidade consolidada. A grande questão que envolve esses programas é a necessidade de se garantir a permanência dos ocupantes originais na terra regularizada e que recebeu benefícios, bem como desenvolver condições para a cidadania. Isso só é possível se a regularização fundiária não for formulada isoladamente e sim no contexto mais amplo das políticas públicas preventivas e dos investimentos diretos em infraestrutura, incorporando a provisão de serviços e a instituição de políticas habitacionais voltadas para a promoção da reforma urbana. Programas de regularização devem ser articulados com outros programas de combate à exclusão, como acesso a crédito, escolarização, etc (CYMBALISTA, 2002).

Por sua vez, a gestão democrática da cidade pressupõe ampla participação social, mas a política urbana, por sua complexidade, tende a se transformar em um assunto de conhecimento em círculos técnicos fechados, envolvendo partes do Executivo e do Legislativo, universidades e associações de classe especializadas. A maior parte da sociedade, organizada ou não, fica geralmente à margem do debate, alheia aos termos técnicos e científicos que envolvem esse assunto.

Os desafios persistem, embora os conselhos de desenvolvimento urbano, as conferências de política urbana, os debates, consultas e audiências públicas, tenham sido idealizados pelo EC para melhorar a interlocução popular, incorporar padrões menos elitistas nos planos e leis urbanísticas e, sobretudo, romper com o histórico de relações perversas e clientelistas entre o Legislativo e os segmentos populares (a exemplo das barganhas em trocas de votos). Com frequência, são veiculadas na imprensa ações de corrupção envolvendo as Câmaras Municipais e os órgãos executivos de planejamento urbano que concedem privilégios a setores empresariais, por meio de alterações na legislação de uso e ocupação do solo da cidade.

Não existe avaliação e fiscalização de decisões referentes aos investimentos públicos e privados nas cidades, pois as Prefeituras não dispõem, na maior parte dos casos, de um sistema de informações acessível a todos os cidadãos interessados.

Assim, a discussão sobre os pressupostos teóricos do Estatuto da Cidade (plano diretor e instrumentos) evidencia uma grande complexidade envolvida em atos como os de coibir a formação de vazios urbanos, regular a ocupação informal e gerir a cidade de forma democrática. Por certo, ao reconhecê-las, o EC acenou para um possível redirecionamento do desenvolvimento urbano, mas, em face das dificuldades envolvidas em sua aplicação efetiva, em nível municipal, o que se verifica, na realidade, é uma continuidade com possível agravamento dos desequilíbrios sociais e dos conflitos de interesse existentes. Fica claro que as normas urbanístico-legais, por si só, são insuficientes para resolver as questões das cidades reais. Estas já detêm um "passivo" e, a cada dia, novos desafios são impostos em razão da velocidade das transformações econômicas 
capitalistas contemporâneas. O aperfeiçoamento das instituições político-administrativas, condição fundamental para a melhoria do ambiente urbano, vai muito além do alcance dos dispositivos legais na esfera do planejamento urbano.

O Estudo do processo de planejamento urbano da cidade de Salvador (Bahia), com vistas aplicação do EC, objeto deste trabalho, demonstra que, na prática, o uso do plano diretor e dos instrumentos urbanísticos não tem beneficiado o espaço coletivo nem tem contribuído para corrigir ou minimizar problemas urbanos, a exemplo da exclusão urbanística, segregação espacial e adensamento excessivo; com base nessa constatação, este artigo tem por objetivo discutir os limites e as possibilidades de aplicação do EC em Salvador, ao final da primeira década do século XXI, com vistas a reduzir as expectativas em relação ao poder do instrumento em si e, ao mesmo tempo, estimular a reflexão sobre novas formas de gestão da cidade. Após esta introdução, as três seções seguintes apresentam a pesquisa qualitativa realizada para a elaboração do texto e a conclusão.

\section{DISCUSSÃO SOBRE SALVADOR: APLICAÇÃO DO ESTATUTO DA CIDADE}

A análise da evolução espacial da cidade de Salvador, Bahia, principalmente após os anos 1940, quando ocorreram grandes transformações urbanas, permite constatar que a ação dos agentes econômicos, públicos e privados, muitas vezes estiveram perfeitamente associadas, com o Estado e a Prefeitura, provendo a infraestrutura necessária para os grandes equipamentos urbanos que foram se instalando paulatinamente, formando novas centralidades, diversificando os usos e atraindo novos investimentos. O pequeno núcleo urbano, existente até o final do século XIX, transformou-se na atual metrópole, terceira do país em porte populacional e com a ocupação urbana atingindo os limites municipais (Figura 1). 


\section{Figura 1}

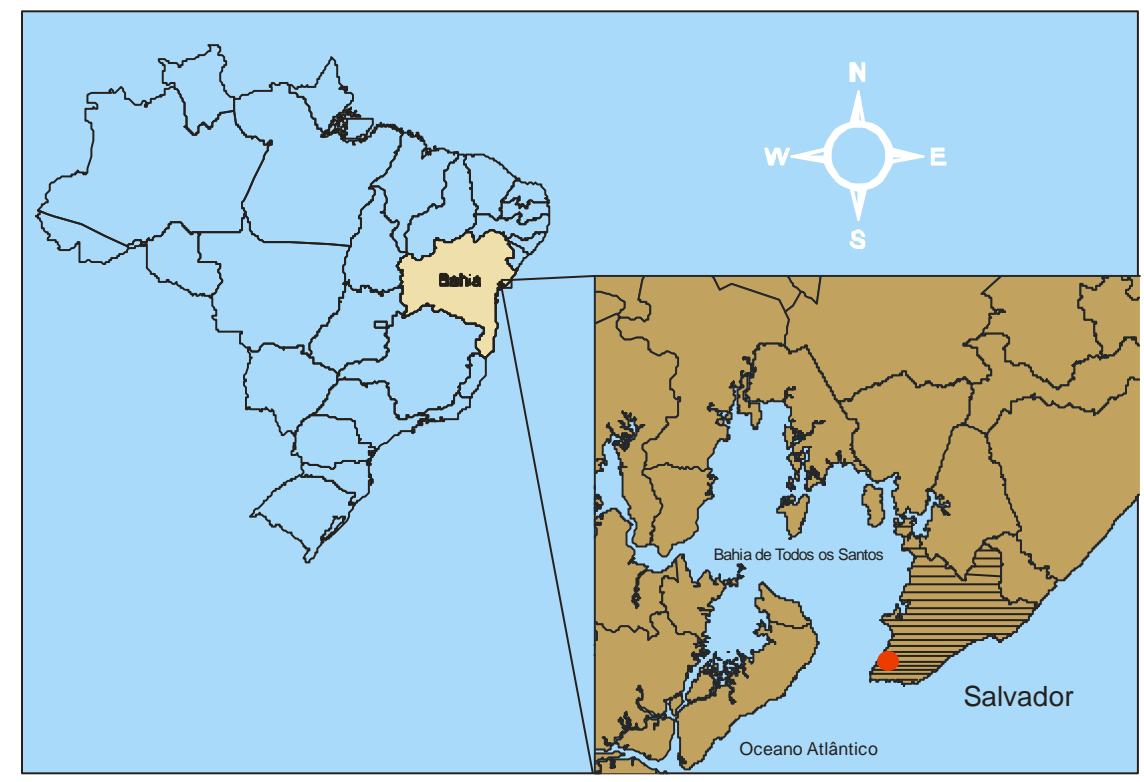

Figura 1 - Localização geográfica do município de Salvador, Bahia. Fonte: Superintendência de Estudos econômicos e Sociais da Bahia (SEI), Base cartográfica digital de Salvador. Nota: Elaboração da autora.

\section{Pesquisa qualitativa: opção metodológica}

O processo de planejamento urbano, como todo processo político, é resultado de um somatório de contribuições de todos os setores sociais, mas, como atividade técnica, na prática é levado a cabo pelos gestores públicos, ocupantes de cargos e funções nos órgãos, responsáveis pela condução das ações de planejamento e remunerados com recursos públicos. Considera-se, pois, que suas atitudes têm grande significância no que toca às possibilidades de êxito dos instrumentos de planejamento urbano, ainda que sejam continuamente influenciados pela dinâmica social, política e econômica local, pelos críticos do setor acadêmico e pelos mecanismos de participação popular.

As pesquisas qualitativas, na Sociologia, trabalham os indivíduos com seus significados, motivações, valores e crenças; estes não podem ser reduzidos às questões quantitativas, pois respondem a noções muito particulares. Entretanto, os dados quantitativos e os qualitativos acabam se complementando (MINAYO, 1996).

Há quem não aceite a dicotomia quantitativo versus qualitativo. Em ciências sociais, a investigação qualitativa foi caracterizada como fonte direta de dados no ambiente natural, constituindo-se o pesquisador no instrumento principal; é uma pesquisa descritiva, em que o 
processo passa a interessar mais que o resultado e os dados são examinados de maneira indutiva, privilegiando-se o significado (BOGDAN e BIKLEN, 1994 apud BOAVENTURA, 2007).

A pesquisa aqui proposta foi elaborada em duas etapas. A parte introdutória, apresentada a seguir, é documental e compreende a análise do processo de elaboração e revisão dos Planos Diretores de Salvador, a partir do Plano Diretor de 1985, quando foram adotados alguns elementos do EC. Esta etapa traduz uma preocupação da autora não só com os produtos (planos), mas com a qualidade dos processos dentro dos quais estes planos são elaborados em Salvador.

A etapa empírica, propriamente dita, é descritiva e analítica, e será apresentada na seção 3. Esta consiste na aplicação de um questionário a grupos de atores sociais envolvidos no processo de elaboração, revisão e discussão dos planos diretores, nas ações de planejamento urbano que envolvem a aplicação do EC, enfim, na construção do pensamento urbanístico soteropolitano do século XXI. Tais atores sociais, em sua maioria, são especialistas e profissionais do planejamento regional e urbano, representantes de grupos e entidades, governamentais ou não; sua formação cultural e ideológica, seu trabalho, e, sobretudo suas opiniões e atitudes, influenciam o pensamento urbanístico local, o que é considerado decisivo na definição do futuro da cidade.

\section{O QUE MUdA NA ERA DO ESTATUTO DA CIDADE E DO PDDU PARTICIPATIVO DO SÉCULO XXI}

O primeiro Plano Diretor de Salvador, nos moldes preconizados pelo Estatuto da Cidade, é de 1985. Esta Lei Municipal (3525/85) criou as Áreas de Proteção Sócio Ecológica (APSES), correspondentes às atuais Zonas Especiais de Interesse Social (ZEIS). Originam-se nessa fase também as primeiras legislações sobre ocupação e uso do solo (LOUS) e sobre a participação comunitária no processo de planejamento. Essa tendência irá consolidar-se com a aprovação do Estatuto da Cidade, em 2001.

Os Planos Diretores de Desenvolvimento Urbano (PDDU) subsequentes, aprovados em 2004 e 2007, foram elaborados como revisões e complementações do Plano de 1985, entretanto, esse processo só se iniciou 1998, em consequência de alterações na LOUS que vinham sendo feitas pela Prefeitura por pressão do setor imobiliário.

O projeto de lei do PDDU 2004 havia sido elaborado sob a coordenação da Secretaria Municipal de Planejamento (SEPLAM) que, em comissão formada por 30 membros, conduziu os trabalhos de revisão em somente 4 encontros, realizados entre 1998 e 2000 . A legislação municipal, então existente, já garantia a participação comunitária, o que fez com que movimentos 
populares organizados, entidades ambientalistas, sindicatos e a Ordem dos Advogados da Bahia questionassem o processo de revisão por não ter sido participativo, conforme determina a lei.

Tendo em vista o questionamento de diversos aspectos técnicos, entidades populares, por meio do Ministério Público Estadual da Bahia e de sua Promotoria de Justiça, acionaram a Prefeitura de Salvador, requerendo a anulação da proposta do PDDU 2004, designando a UFBA para periciar o Plano e elaborando uma minuta de Termo de Ajustamento e Conduta (TAC). Mas a SEPLAM recusou-se a celebrar o TAC e a Prefeitura enviou o Projeto de Lei para a Câmara Municipal, subjudice. Assim, a Lei Municipal 6.586/04 (PDDU 2004), foi aprovada na Câmara Municipal de Salvador em processo bastante conturbado. O documento foi considerado ilegítimo no tocante à participação popular e já nasceu necessitando de nova revisão (BRASIL, 2010).

De fato, já em 2005, a Prefeitura Municipal de Salvador estabeleceu extensa programação de reuniões com os segmentos acadêmico, profissional, comunitário e político, de modo a criar um clima mais participativo para a revisão do PDDU de 2004, resgatando sua legitimidade e, principalmente, adaptando-o aos ditames do Estatuto da Cidade, cuja promulgação, em 2001, tornara bem mais contundentes as controvérsias e críticas geradas no processo anterior de revisão (TEIXEIRA, 2006).

Ao estabelecer seus Princípios da Política Urbana, o documento do PDDU 2007 já demonstra claramente o alinhamento de suas diretrizes com a função social da cidade, a função social da propriedade, o direito à cidade sustentável, a equidade social, o direito à informação e a gestão democrática da cidade - princípios básicos do Estatuto da Cidade.

Todavia, o plano tratou a maior parte dos temas como um protocolo de boas intenções, adotando um discurso harmonioso e consoante às tendências mundiais, mas desligado da realidade urbana de Salvador. Na questão da preservação, por exemplo, está condizente com ênfase na gestão ambiental, mas é ambíguo quanto ao estabelecimento de bases para o licenciamento de empreendimentos e atividades no território. Do modo análogo, a política cultural também segue a receita da chamada "economia da cultura" - uma linha de pensamento, reforçada na esteira do processo de globalização, que tende a valorizar as identidades locais como fatores de produção que proporcionam "vantagens competitivas" em relação a outras cidades - mas não especifica diretrizes claras para que tais objetivos sejam atingidos, tendo em vista a grande desigualdade social e econômica e os altos índices de desemprego da cidade e sua região metropolitana.

As diretrizes para a habitação de baixa renda foram privilegiadas no PDDU 2007, a exemplo de 2004. A inovação consiste no reconhecimento da questão dos assentamentos informais como "abrangente" por envolver a maior parcela da população residente. O instrumento ZEIS é então 
valorizado no que se refere à regularização fundiária e urbanística das favelas. Todavia, o PDDU 2007 não propôs uma política habitacional global para o município de Salvador.

Sob o título "Dos Serviços Urbanos", encontra-se um vasto arsenal de temas como saneamento ambiental, saúde, educação, assistência social, lazer, recreação e esportes, segurança nutricional e abastecimento alimentar, iluminação pública, cemitérios e serviços funerários, defesa civil, segurança pública, energia e telecomunicações. É ilusório pretender que um plano trate de tão extensa gama de temas de forma satisfatória. Alguns temas acabam se transformando em "planos dentro do plano", como o saneamento ambiental, cujo problema é remetido à criação futura do Sistema Municipal de Saneamento Ambiental.

Tratamento diferenciado é conferido pelo PDDU 2007 ao deslocamento de pedestres, de ciclistas e de pessoas com deficiência ou mobilidade reduzida, com a definição de diretrizes e proposições que priorizam a observância de suas necessidades específicas. Todavia, o plano não indica ações concretas no sentido da consecução de tais observâncias. Tal qual registrado no parecer do CREA-BA (CONSELHO REGIONAL DE ENGENHARIA, ARQUITETURA E AGRONOMIA DA BAHIA, 2007), o tratamento dado aos corredores viários estruturais de Salvador prioriza o automóvel individual não fazendo referências aos meios alternativos de transporte, nem mesmo ao pedestre, elemento proeminente, de acordo com os padrões modernos de mobilidade urbana. 0 plano se omite em relação ao fato de que tais corredores, do mesmo modo que veículos, atraem pessoas, justamente por concentrarem os polos de comércio e os principais serviços urbanos.

O coração do PDDU 2007, entretanto, está no título "Do Ordenamento Territorial". Este contém a materialização, no espaço e no território da cidade, das diretrizes e proposições definidas no texto. Neste aspecto o plano é mais preciso e pragmático, aumentando consideravelmente as chances de aplicação e denotando que, neste caso, o discurso e a prática se conectam, ao contrário dos outros temas, tratados de forma mais abstrata. A definição de coeficientes de aproveitamento, básico e máximo, por exemplo, um tema caro aos setores da construção civil e imobiliário, é bastante explícita; outro exemplo é a fórmula de cálculo do valor do potencial construtivo, negociado por meio da Transferência do Direito de Construir (TRANSCON), definido por uma equação matemática expressa no artigo 262 da seção 6 do capítulo VI.

Segundo informações do Sindicato da Indústria da Construção Civil do Estado da Bahia (SINDUSCON) (2008), houve um incremento de 179\% no número de empreendimentos no primeiro semestre de 2008, quando foram lançadas 9.183 novas unidades habitacionais, com relação ao mesmo período de 2007. Já as vendas de imóveis novos, no primeiro semestre de 2008, cresceram 153\%, com a comercialização de 7.269 unidades (Figura 2). 
Em relação ao número de alvarás de construção concedidos e certificados de habite-se fornecidos pela Superintendência de Controle e Uso do Solo (SUCOM) em Salvador, constatou-se também um aumento de mais de $65 \%$ em relação ao total de área construída aprovada. Foram liberados de janeiro a agosto de 2007, 1.492.272,93 $\mathrm{m}^{2}$, enquanto que no mesmo período de 2008 foram liberados 2.276.027,12 m², (SINDICATO DA INDÚSTRIA DA CONSTRUÇÃO CIVIL DO ESTADO DA BAHIA, 2008).

\section{Figura 2}

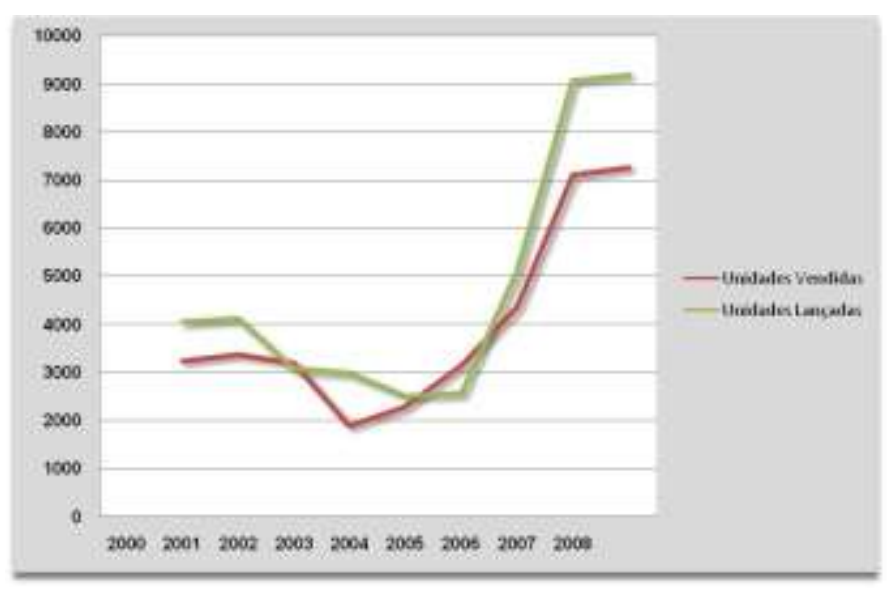

Figura 2 - Número Total de Unidades Residenciais Lançadas e Vendidas em Salvador, Bahia. Fonte: SINDUSCONBA (2008). Nota: Elaboração da autora.

De acordo com dados de 2006, dos imóveis vendidos em Salvador, 95,29\% tinham valor acima de $\mathrm{R} \$ 75$ mil e destes, $51,71 \%$ tinham valor de mercado entre $\mathrm{R} \$ 125$ mil e $\mathrm{R} \$ 750$ mil. A variação dos custos do metro quadrado construído na Avenida Paralela e em Armação (orla atlântica), por exemplo, registraram alta de 30\%, chegando a aproximadamente R\$̣ três mil (SINDICATO DA INDÚSTRIA DA CONSTRUÇÃO CIVIL DO ESTADO DA BAHIA, 2008).

Na análise das proposições contidas no PDDU 2007 para as áreas de orla marítima, o tema central é o gabarito de altura das edificações. Para a Prefeitura, os gabaritos foram revistos em relação a 2004 no sentido de possibilitar um melhor aproveitamento dos espaços da orla, favorecendo sua renovação urbanística, edilícia e econômica (TEIXEIRA, 2006).

Entretanto, em Parecer encaminhado à Câmara de Vereadores de Salvador, o Conselho Regional de Engenharia e Arquitetura da Bahia (CREA-BA) teceu críticas severas ao PDDU no que se refere a esse aspecto. Segundo o órgão, o tema do gabarito foi inserido ao corpo do Plano sem justificativa e tampouco foi apresentado estudo fundamentado para definição dos critérios 
utilizados para a determinação dos gabaritos. Segundo o órgão, tais critérios, técnicos e legais, deveriam considerar as legislações federais e estaduais vigentes e contemplar as análises dos planos de massas, os estudos de impacto de vizinhança e impacto ambiental, o conforto ambiental e o sombreamento (CONSELHO REGIONAL DE ENGENHARIA, ARQUITETURA E AGRONOMIA DA BAHIA, 2007).

Não obstante, a própria Prefeitura reconheceu a importância da verticalização da orla marítima para efeito de aumento da receita municipal via arrecadação de impostos. As Taxas de Licenciamento (TL), Imposto Sobre Serviços (ISS), Imposto Predial e Territorial Urbano (IPTU) e outros tributos decorrentes da verticalização da orla passariam a dar mais "lucro" ao município, que possui a segunda pior arrecadação municipal per capita do Brasil; a verticalização foi considerada a saída natural para o mercado imobiliário, pois restariam apenas $14 \%$ de terrenos vazios em Salvador (O QUE..., 2007).

Essas informações dão uma noção da pressão do mercado imobiliário sobre os terrenos urbanos. Como justificativa para a flexibilização da legislação urbanística nas áreas nobres, ressurge constantemente o mote da atração de investimentos e geração de emprego e renda para a cidade. Salvador precisa crescer, a cidade não pode ficar engessada. Precisamos de um Plano Diretor de Desenvolvimento Urbano (PDDU) e de uma Lei de Uso do Solo que atraiam investimentos e gerem postos de trabalho para que Salvador se torne uma capital fomentadora de serviços em áreas da Cidade Alta, da Cidade Baixa, Orla marítima, Subúrbio e Ilhas, criando oportunidade de trabalho indistintamente para todas as camadas sociais, assim como promovendo o lazer e a cultura (SALVADOR, 2007, p. 1).

Em termos de visão geral sobre o PDDU 2007, aponta-se a sua adesão quase completa - à exceção da política de habitação de interesse social - a uma visão de cidade privatista, segmentada e de curto prazo, que compromete seriamente as possibilidades de constituição de um espaço urbano generoso e inclusivo (FERNANDES, 2008).

No que se refere aos instrumentos urbanísticos preconizados pelo EC, todos, sem exceção, foram contemplados pelo PDDU 2007, em que pese alguns, como as (ZEIS) e a Transferência do Direito de Construir (TRANSCON), já estarem regulamentados por lei municipal anterior ao EC. Todavia, a modalidade TRANSCON é utilizada em Salvador há mais de vinte anos e permite ao proprietário de um imóvel urbano exercer em outro local, ou alienar mediante escritura pública, o direito de construir conferido ao seu imóvel pela legislação urbanística em vigor, quando este for considerado de interesse público, por intermédio da emissão de uma Certidão de Potencial Construtivo, onerosa, o que gera renda à Prefeitura. Porém, o instrumento tem sido utilizado de forma indiscriminada e sem controle social, funcionando como "moeda de troca" entre 
funcionários corruptos e empresários interessados em aumentar sua lucratividade na especulação imobiliária, conforme foi recentemente denunciado o esquema de negociações clandestinas das certidões TRANSCON, envolvendo a Superintendência de Ordenamento e Controle do Uso do Solo (SUCOM) da Prefeitura de Salvador e grandes empresários da construção civil atuantes na cidade e que ensejou um processo de investigação que está em curso (ROCHA, 2010).

Por outro lado, outros importantes instrumentos de Política Urbana também habilitados pelo PDDU 2007, ainda carecem de regulamentação por lei específica. Ou porque se considera impróprio fazer seu detalhamento no corpo do plano, ou ainda porque demandam informações cadastrais atualmente não disponíveis. No primeiro caso destaca-se o Estudo de Impacto de Vizinhança (EIV), no segundo caso incluem-se o Direito de Preempção, o Parcelamento, Edificação e Utilização Compulsórios, e até mesmo a destinação de áreas para criação de novas ZEIS, por exigirem a identificação imobiliária dos imóveis passíveis de afetação. Por sua vez, instrumentos como as Operações Urbanas Consorciadas demandam até mesmo estudos de viabilidade, por exigirem garantias de longo prazo, formas complexas de monitoramento e gestão, e de articulação público-privada (TEIXEIRA, 2006).

A dificuldade da Prefeitura em elaborar uma Planta Cadastral da Cidade remonta à década de 1940, sendo uma das queixas de Mário Leal Ferreira, engenheiro responsável pelo Escritório do Plano de Urbanismo da Cidade de Salvador (EPUCS). O cadastro e, de modo mais amplo, o estabelecimento de um sistema de informações permanentemente atualizado, é uma questão não resolvida que prejudicou o EPUCS, o Plano de Desenvolvimento Urbano da Cidade do Salvador (PLANDURB), o Estudo de Uso do Solo e Transportes da Região Metropolitana de Salvador (EUST) e outras experiências de planejamento urbano em Salvador (PENTEADO, 1991).

Não obstante, a prática de acordos entre poder público municipal e os setores empresariais, em Salvador, funciona como meio indireto de financiamento de empreendimentos imobiliários privados; dentre estes o exemplo mais contundente é o projeto do Parque do Aeroclube, um terreno público, situado à beira mar, no bairro da Boca do Rio. Parte desta área foi concedida pela Prefeitura Municipal de Salvador, em meados da década de 1990, por meio do instrumento Concessão Real de Uso, a um grupo empresarial para a construção de um Shopping Center, em troca da construção e gestão, por 30 anos, de um parque público vizinho a este. O Shopping Aeroclube Plaza Show foi inaugurado em 1999 e, desde então, muitas ações têm tramitado na justiça numa discussão interminável entre advogados do grupo empresarial e procuradores da Prefeitura. A construção do parque público, também denominado Parque Atlântico (que deveria iniciar-se simultaneamente à construção do Shopping) não aconteceu até o presente momento. A Secretaria de Planejamento da Prefeitura não cobrou dos empresários a falta 
de cumprimento do cronograma das obras e cláusulas referentes a contrapartidas sociais, a exemplo da construção de uma passarela para pedestres, constante no acordo de 2007, as quais desapareceram do texto do contrato, após sua assinatura pelas partes (JUSTIÇA..., 2008; POSTIGO..., 2008).

De fato, após 14 anos de embates, a área continua abandonada com consequente degradação de valioso espaço público, em prejuízo da população de Salvador. A área ocupada pelo shopping continua a ser explorada comercialmente.

\section{O QUE PENSAM GESTORES PÚBLICOS E ESPECIALISTAS}

Embora vivamos sob o império da participação popular, é inegável a importância dos gestores públicos e especialistas para o planejamento urbano; em que pese suas implicações políticas, culturais e sociais, a atividade é essencialmente técnica e requer conhecimento e experiência para seu desempenho. O Brasil tem bons exemplos de profissionais desta área, cujo preparo técnico aliado a uma visão política avançada, costumam revolucionar as cidades onde atuam (é o caso de Jaime Lerner em Curitiba, para citar apenas um). Do mesmo modo, apesar da integração entre os setores sociais estar na ordem do dia, na prática, a gestão urbana se divide por tema de interesse. Assim é a estrutura do poder executivo municipal de Salvador e dos órgãos responsáveis pelo planejamento urbano da cidade. Também os profissionais locais estão, normalmente, ligados a áreas do conhecimento que se desdobram em temas e subtemas, de tal maneira que este funcionamento se reproduz na estrutura do próprio PDDU 2007. Esta premissa foi o ponto de partida para o desenho da pesquisa qualitativa, cujo modelo é descrito a seguir.

\section{O desenho da Pesquisa}

A pesquisa foi construída com base nos grandes temas priorizados pelo PDDU 2007 de Salvador e seu relacionamento com os grupos sociais mais fortemente envolvidos na discussão dos PDDU's; tais grupos foram identificados por meio do levantamento do processo de elaboração e revisão dos PDDU's de Salvador, em 2004 e 2007, conforme exposto na seção anterior. Essa associação resultou em uma matriz de dez linhas por seis colunas onde os cruzamentos entre os temas e os grupos selecionados significaram, pelo menos, sessenta possibilidades de consulta.

Buscou-se, objetivamente, a opinião dos envolvidos sobre o processo de planejamento urbano, a política urbana, as possibilidades de êxito e as principais limitações para a aplicação dos instrumentos urbanísticos postulados pelo EC, em Salvador, em 2010. Para tanto, o instrumento utilizado foi um questionário com onze perguntas em formato semiestruturado que, além de 
respostas diretas, propiciou também um certo grau de liberdade para o profissional que desejasse tecer comentários.

O esforço consistiu em se obter o maior número de retornos possível e em igual número para todos os setores, de modo que tivessem o mesmo peso na avaliação quantitativa. Das 50 solicitações enviadas, com questionário em anexo, a profissionais de órgãos municipais, estaduais, entidades de classe, associações não governamentais, associações privadas, associações populares, universidades e também profissionais independentes - representantes dos setores selecionados - o maior retorno obtido foi de $36,72 \%$ de respostas, portanto, e $28 \%$ de não respostas, distribuídas desigualmente nos setores de opinião pesquisados. Quanto maior a recusa dos profissionais em atender à solicitação feita, maior o número de questionários enviados ao setor correspondente, de modo a equilibrar o número de respostas por setor. Assim, além do conteúdo das respostas, foi possível também analisar o grau de atendimento ou resistência dos setores em atender à solicitação feita - no caso, as não respostas (Tabela 1).

Além de uma noção do grau de atendimento e interesse dos profissionais dos setores selecionados pela questão da aplicação do EC em Salvador e da visão geral do grupo sobre o tema, o modelo possibilitou que as respostas obtidas fossem distribuídas nas áreas de interesse do PDDU, correspondentes à atuação dos especialistas. Permite também uma visão por cruzamentos entre temas e setores, uma visão por grupo - na coluna - e uma visão por tema - na linha, conforme distribuição na matriz (Tabela 2).

Tabela 1

\begin{tabular}{|c|c|c|c|c|c|c|c|c|}
\hline & MUNICIPAL & ESTADUAL & UNIVERSITÁRIO & $\begin{array}{l}\text { MOVIMENTOS } \\
\text { POPULARES, } \\
\text { ONGS, } \\
\text { ASSOCIAÇÕES } \\
\text { PROFISSIONAIS }\end{array}$ & $\begin{array}{c}\text { ASSOCIAÇÕES } \\
\text { DA } \\
\text { CONSTRUÇÃO } \\
\text { CIVIL E DO } \\
\text { MERCADO } \\
\text { IMOBILIÁRIO }\end{array}$ & $\begin{array}{c}\text { CONSULTORES } \\
\text { INDEPENDENTES }\end{array}$ & TOTAL & TOTAL (\%) \\
\hline \multicolumn{9}{|l|}{ SOLICITAÇÕES } \\
\hline FEITAS & 11 & 10 & 7 & 6 & 9 & 7 & 50 & $100 \%$ \\
\hline RESPOSTAS & 6 & 6 & 6 & 6 & 6 & 6 & 36 & $72 \%$ \\
\hline $\begin{array}{l}\text { RESPOSTAS } \\
\text { (\% por setor) }\end{array}$ & $64 \%$ & $71 \%$ & $93 \%$ & $100 \%$ & $79 \%$ & $93 \%$ & - & - \\
\hline NÃO RESPOSTAS & 5 & 4 & 1 & 0 & 3 & 1 & 14 & $28 \%$ \\
\hline $\begin{array}{l}\text { NÃO RESPOSTAS } \\
\text { (\% por setor) }\end{array}$ & $36 \%$ & $29 \%$ & $7 \%$ & $0 \%$ & $21 \%$ & $7 \%$ & - & . \\
\hline
\end{tabular}


Tabela 1 - Atendimento dos setores sociais selecionados à solicitação de retorno do questionário enviado. Fonte: Pesquisa Especialistas e Estatuto da Cidade em Salvador-Bahia, Novembro/2010.

Tabela 2

\begin{tabular}{|c|c|c|c|c|c|c|c|}
\hline & $\begin{array}{c}1 \\
\text { MUNICIPAL }\end{array}$ & $\stackrel{2}{\stackrel{2}{\text { ESTADUAL }}}$ & $\begin{array}{c}3 \\
\text { UNIVERSITÁRIO }\end{array}$ & $\begin{array}{c}4 \\
\text { MOVIMENTOS } \\
\text { POPULARES, ONGS, } \\
\text { ASSOCIAÇÕES } \\
\text { PROFISSIONAIS }\end{array}$ & $\begin{array}{c}5 \\
\text { ASSOCIAÇÕES DA } \\
\text { CONSTRUÇÃOA } \\
\text { CIVIL E DO } \\
\text { MERCADO } \\
\text { IMOBILIÁRIO }\end{array}$ & $\begin{array}{c}6 \\
6 \\
\text { CONSULTORES } \\
\text { INDEPENDENTES }\end{array}$ & $\begin{array}{c}\text { TOTAL DE } \\
\text { RESPOSTAS POR } \\
\text { TEMA }\end{array}$ \\
\hline 1 DESENVOLVIMENTO ECONÔMICO & 1 & 1 & 1 & & 1 & 1 & 5 \\
\hline 2 MEIO AMBIENTE & 1 & 1 & & 1 & 1 & 1 & 5 \\
\hline 3 CULTURA & & & 1 & 1 & & & 2 \\
\hline 4 HABITAÇÃO & 1 & & & 1 & 1 & & 3 \\
\hline 5 SERVIÇOS URBANOS BÁSICOS & & & 1 & & & 1 & 2 \\
\hline 6 ORDENANEMTO TERRITORIAL & 1 & 1 & & 1 & 1 & & 4 \\
\hline 7 MOBILIDADE URBANA & & 1 & 1 & & 1 & 1 & 4 \\
\hline 8 ÁREAS DE VALOR AMBIENTAL E CULTURAL & 1 & 1 & 1 & 1 & & 1 & 5 \\
\hline 9 INSTRUMENTOS DA POLITICA URBANA & & & & & 1 & & 1 \\
\hline 10 DESENVOLVIMENTO POLÍTICO E INSTITUCIONAL & 1 & 1 & 1 & 1 & & 1 & 5 \\
\hline TOTAL DE RESPOSTAS POR SETOR & 6 & 6 & 6 & 6 & 6 & 6 & 36 \\
\hline
\end{tabular}

Tabela 2 - Distribuição das respostas obtidas na pesquisa, de acordo com os temas do PDDU 2007 e os setores sociais selecionados. Fonte: Pesquisa Especialistas e Estatuto da Cidade em Salvador-Bahia, Novembro/2010.

\section{Análise e discussão dos resultados}

Em uma pesquisa, particularmente do tipo qualitativa, nem tudo é controlável e naturalmente surgem dificuldades que devem ser contornadas de modo a preservar a sua essência. Em primeiro lugar, o envio das perguntas via correio eletrônico apresentou algumas desvantagens, pois muitos profissionais não abrem diariamente suas caixas postais ou simplesmente não respondem às mensagens. Além da carta de apresentação, identificando a pesquisadora e explicando os propósitos da pesquisa, foram necessários muitos contatos telefônicos e pessoais subsequentes para reiterar a importância do trabalho e solicitar que os profissionais enviassem suas respostas.

A falta de presteza pode ser entendida como uma forma de reação ao objeto da pesquisa. Conforme os dados apresentados na Tabela 1, fica evidente que o pronto atendimento à solicitação, feita através do retorno do questionário respondido, foi completo apenas no setor dos movimentos populares, organizações não governamentais e de classe - que atendeu a $100 \%$ das solicitações enviadas; este setor foi seguido pelos profissionais liberais (consultores), com atuação diversa no campo do planejamento regional e urbano da cidade, sem vínculo com instituições 
governamentais, bem como pelo setor universitário - ambos obtiveram $7 \%$ de não resposta. Esta participação demonstra um maior interesse dos representantes das associações populares, professores e pesquisadores pelo tema da aplicação do EC em Salvador. Isso parece lógico em função de sua independência relativa no que diz respeito à elaboração de planejamento público, denotando, de um modo geral, uma familiaridade com as questões abordadas.

Os setores municipal e estadual resistiram mais em responder às questões, obtendo os maiores percentuais de não resposta, 35\% e 29\% respectivamente. É lamentável que estes setores, justamente os responsáveis pelo comando do processo de planejamento público, por meio de seus especialistas, estejam tão desinteressados pela aplicação do EC em Salvador e, portanto, não se pode aceitar a falta de tempo como uma desculpa. Destaca-se que, nestes setores, foi preciso grande insistência para se conseguir uma participação mínima dos profissionais nesta pesquisa.

Por outro lado, as associações de empresas da construção civil e imobiliárias obtiveram o terceiro percentual mais alto de não resposta (7\%). Foi alegado que muitos profissionais desse setor não conhecem o EC e se consideram inaptos para responder às perguntas. É um fato grave o desconhecimento da lei e o descompromisso com o interesse e o espaço público por parte de segmentos econômicos tão importantes na cidade.

Contudo, é possível observar que o desenvolvimento econômico, o meio ambiente, as áreas de valor ambiental e cultural e o desenvolvimento político e institucional são os temas melhor representados na amostra, seguidos pelos temas do ordenamento territorial e da mobilidade urbana. Isso explica, em parte, comentários mais voltados para esses aspectos, de um modo geral.

Verificadas as questões do atendimento e da preponderância de alguns temas, a análise teve por foco o resultado global do conjunto de especialistas e a participação dos setores nas respostas. O número reduzido de respostas não permite que a pesquisa seja valorizada sob o ponto de vista estatístico, mas sim pelas tendências sinalizadas e pela qualidade dos comentários feitos. Estes pontos apresentam grande riqueza no que toca à expectativa deste grupo de profissionais de Salvador sobre a aplicação do EC e o processo de planejamento urbano, dez anos depois de aprovada a lei.

A seguir os principais resultados da pesquisa Estatuto da Cidade em Salvador-Bahia, realizada em novembro de 2010. Os resultados quantitativos estão em formato de gráficos, indicados ao longo do texto por figuras numeradas em sequência.

O primeiro bloco do questionário indaga sobre o Estatuto da Cidade (EC) de modo objetivo e as possibilidades de respostas são categóricas, em que pese haver espaço para comentários em todas as perguntas. 
A primeira questão se refere ao conhecimento do especialista sobre o PDDU 2007, ao que três quartos responderam positivamente e um quarto se dividiu entre aqueles que não conhecem e aqueles que conhecem superficialmente (Figura 3).

Figura 3

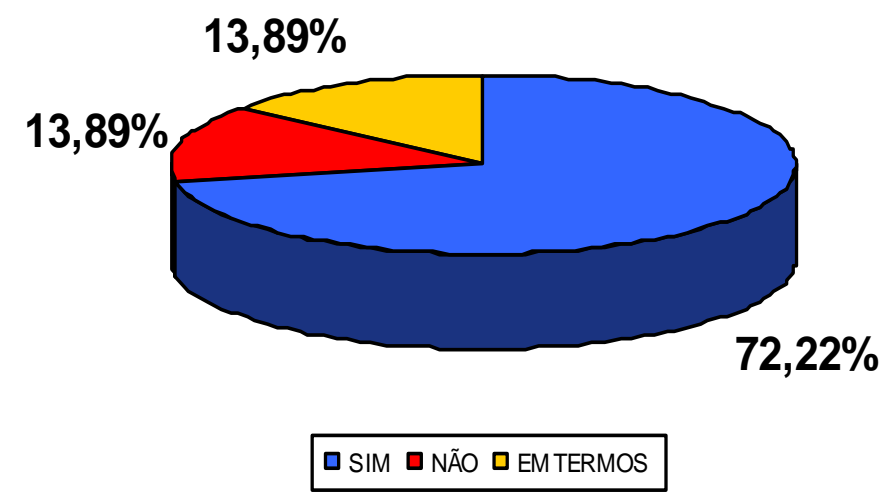

Figura 3 - Especialistas que conhecem o PDDU 2007 de Salvador (Lei Municipal n 7400/08). Fonte: Pesquisa Especialistas e Estatuto da Cidade em Salvador-Bahia, Novembro/2010. Nota: Elaboração da autora.

Entre os que conhecem o EC, a maioria é do setor de universitário seguido pelo de consultores; entre os que o conhecem "em termos" aparecem profissionais de todos os setores, mas a maior participação é do setor das organizações não governamentais e de classe; por último, os que não conhecem o EC pertencem, em sua maioria, ao setor empresarial.

A segunda questão se refere aos efeitos que a política urbana municipal, ou a falta dela, produz em Salvador; a grande maioria dos especialistas consultados opinou pelos efeitos negativos e um pequeno percentual opinou pela ausência de efeitos. Ocorre que alguns interpretam uma ausência de política urbana como produtora de efeitos negativos, enquanto outros consideram esta ausência uma espécie de "não-política", algo que não produz nenhum efeito (Figura 4).

Os especialistas mais críticos lamentaram a inexistência de algum tipo de política urbana, mesmo incipiente, na cidade. Como razões para essa ausência apontaram: a forte ingerência do setor imobiliário e a subserviência da Prefeitura ao atendimento de necessidades privadas. Dentre os críticos, alguns observaram também que a política urbana, frequentemente, é formulada para o atendimento de interesses do setor turístico. A definição de uma política urbana adequada para Salvador, portanto, ainda é uma lacuna grave, na visão da maioria dos especialistas consultados nesta pesquisa. 
Figura 4

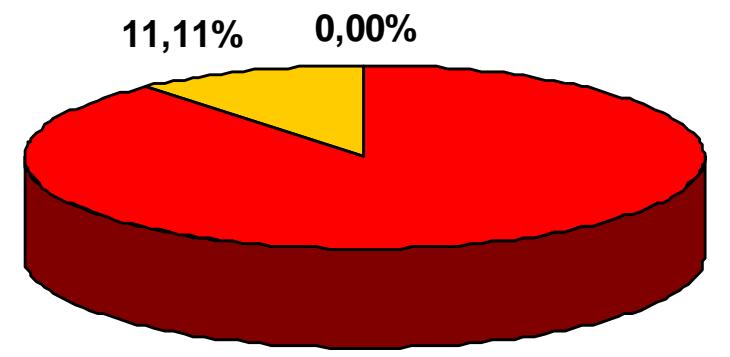

$88,89 \%$

口 EFEITOS POSITIVOS ם EFEITOS NEGATIVOS ם NENHUM EFEITO

Figura 4 - Efeitos produzidos pela política urbana (ou a falta dela) em Salvador. Fonte: Pesquisa Especialistas e Estatuto da Cidade em Salvador-Bahia, Novembro/2010. Nota: Elaboração da autora.

Por outro lado, a maior parte dos especialistas consultados não reconhece os princípios da política urbana, adotados pelo PDDU 2007 e norteados pelos ideais do EC, nas ações ou práticas públicas de planejamento urbano de Salvador. Este foi o tema da terceira questão e, quase um quarto dos profissionais reconheceu "em termos" porque acredita que os princípios são adotados segundo a conveniência ou interesse de setores específicos. As ações ou práticas públicas de mediação de conflitos e de interesse público, segundo estes, são as mais difíceis de implementar (Figura 5).

\section{Figura 5}

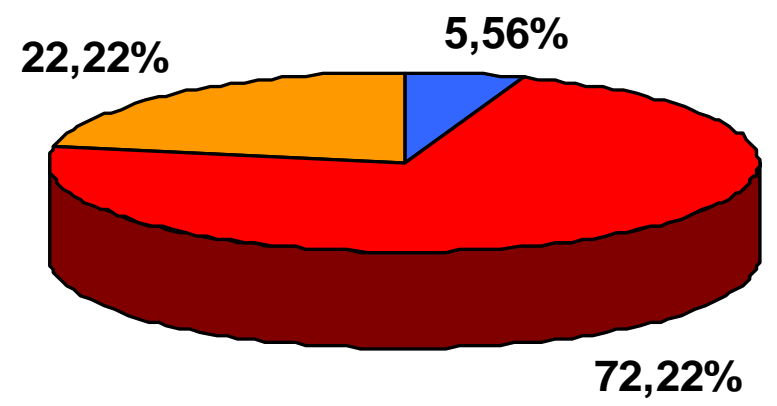

$\square$ SIM $\square$ NÃO $\square$ EMTERMOS

Figura 5 - Especialistas que reconhecem os princípios da política urbana adotados pelo PDDU 2007, norteados pelos ideais do Estatuto da Cidade, nas práticas públicas de planejamento urbano de Salvador. Fonte: Pesquisa Especialistas e Estatuto da Cidade em Salvador-Bahia, Novembro/2010. Nota: Elaboração da autora. 
Dentre os que não reconheceram os princípios do EC estão os profissionais dos setores das organizações não governamentais e de classe e os do setor universitário. Já no grupo que reconheceu "em termos", a maior participação foi de profissionais do setor de consultores seguido pelo empresarial.

Na exposição feita no capítulo anterior, observou-se que houve um descontentamento por parte de diversos setores sociais por ocasião da aprovação dos PDDU's de 2004 e 2007 em Salvador. Constatou-se também que as implementações não lograram sucesso, ficando no papel a maior parte das diretrizes inspiradas no $\mathrm{EC}$, que visavam à melhoria do ambiente urbano e à valorização do espaço público. Foi indagado, pois, aos especialistas, qual sua impressão sobre os impactos que a mudança de paradigma, representada pela figura do EC e incorporada ao PDDU 2007, causou em Salvador. A metade declarou que a mudança causou impactos negativos porque a adoção dos instrumentos urbanísticos do EC aconteceu de forma invertida e em práticas "clientelistas" o que pode estar complicando a situação. Entretanto, quase 14\% dos profissionais reconheceram algum impacto positivo na cidade em razão da mudança de paradigma. (Figura 6).

\section{Figura 6}

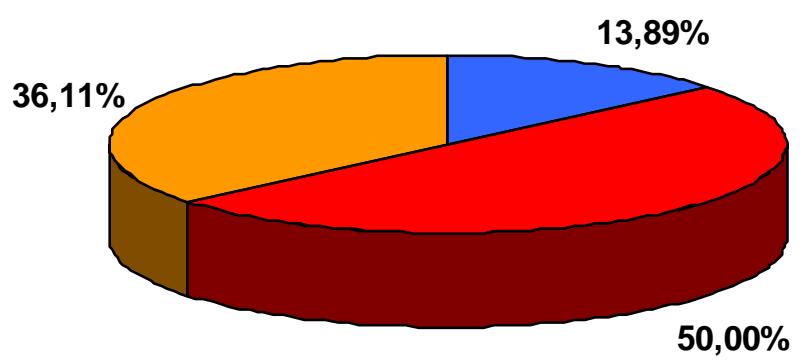

口 IM PACTOS POSITIVOS — IM PACTOS NEGATIVOS ם NENHUM IMPACTO

Figura 6 - Impressão dos Especialistas sobre os impactos causados em Salvador pelo PDDU 2007 e pela mudança de paradigma representada pelo Estatuto da Cidade. Fonte: Pesquisa Especialistas e Estatuto da Cidade em Salvador-Bahia, Novembro/2010. Nota: Elaboração da autora.

Para aqueles especialistas que reconhecem os impactos positivos relacionados à mudança de paradigma por meio do EC, houve progressos nas áreas de saneamento ambiental e habitacional; todavia, para poder imprimir um novo direcionamento à cidade, conforme reza o texto do PDDU 2007, o modelo de gestão praticado ainda necessita de aperfeiçoamento. Para aqueles que se posicionaram pelos impactos negativos (50\%), os problemas da gestão estão relacionados à predominância de interesses imobiliários e fundiários dos agentes econômicos no município, em prejuízo do interesse público - a exemplo de permitir o adensamento da cidade e o avanço sobre as áreas verdes. Neste grupo predominaram os setores universitário e de consultores. 
Para os profissionais que reconheceram os impactos positivos (mais de 13\%), os programas de saneamento básico realizados e a urbanização de favelas foram importantes para a cidade. Neste grupo imperou o setor municipal seguido pelo estadual.

O instrumento da Concessão de Uso Especial da União, utilizado para regularização fundiária em Alagados e na Gamboa de Baixo, foi apontado como exemplo prático positivo de aplicação do instrumento, com a ressalva, porém, de que seus impactos se relacionam mais com a valorização da cidadania do que com a questão urbanística, propriamente dita. À exceção dessas aplicações e do aumento dos coeficientes de aproveitamento nas edificações mais recentes, não foram citados outros exemplos de aplicação dos instrumentos do EC, no âmbito urbanístico, em Salvador.

A respeito das chances de êxito do Estatuto, via acompanhamento de diretrizes do PDDU 2007, as respostas positivas demonstraram que uma boa parte $(36,11 \%)$ dos especialistas está otimista; uma pequena parte (13,89\%) está pessimista e metade deles é cautelosa (50\%) (Figura 7).

\section{Figura 7}

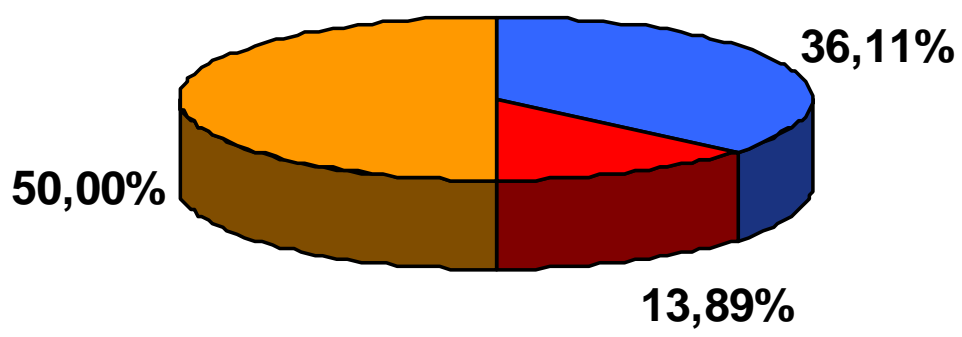

口SIM ロNÃO QEM TERMOS

Figura 7 - Especialistas que acreditam que adotar os princípios do Estatuto da Cidade aumenta as chances de se atingirem as metas propostas pelo PDDU 2007 para Salvador. Fonte: Pesquisa Especialistas e Estatuto da Cidade em Salvador-Bahia, Novembro/2010. Nota: Elaboração da autora.

A seguir a representação gráfica da expectativa dos profissionais relativa à aplicação do EC, conforme os setores em que estão inseridos. 


\section{Figura 8}

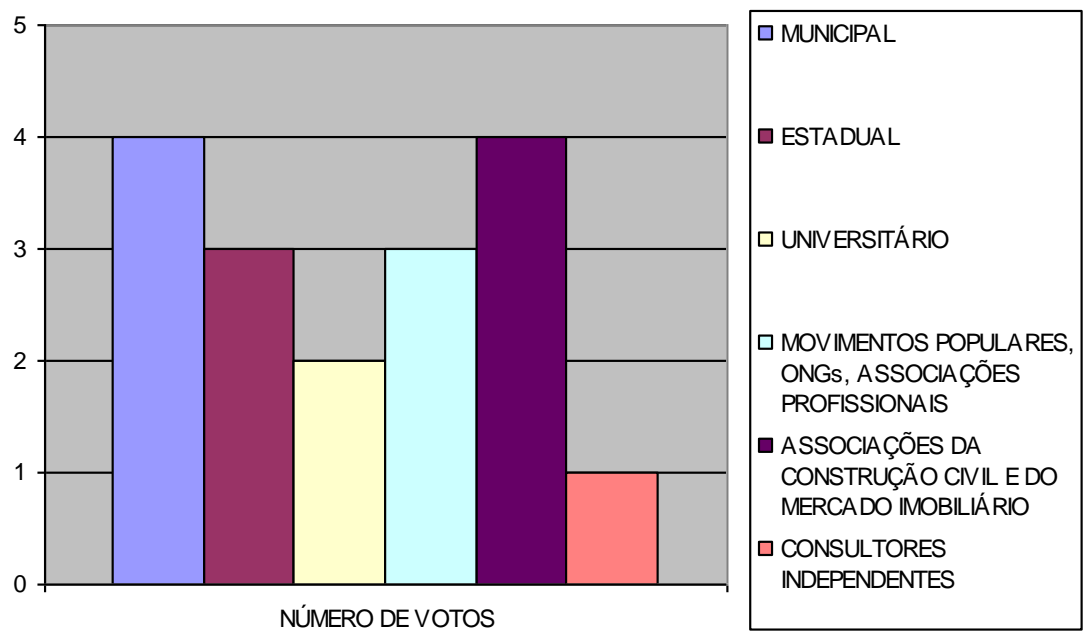

Figura 8 - Setores dos especialistas que estão otimistas em relação à aplicação do Estatuto da Cidade em Salvador. Fonte: Pesquisa Especialistas e Estatuto da Cidade em Salvador-Bahia, Novembro/2010. Nota: Elaboração da autora.

\section{Figura 9}

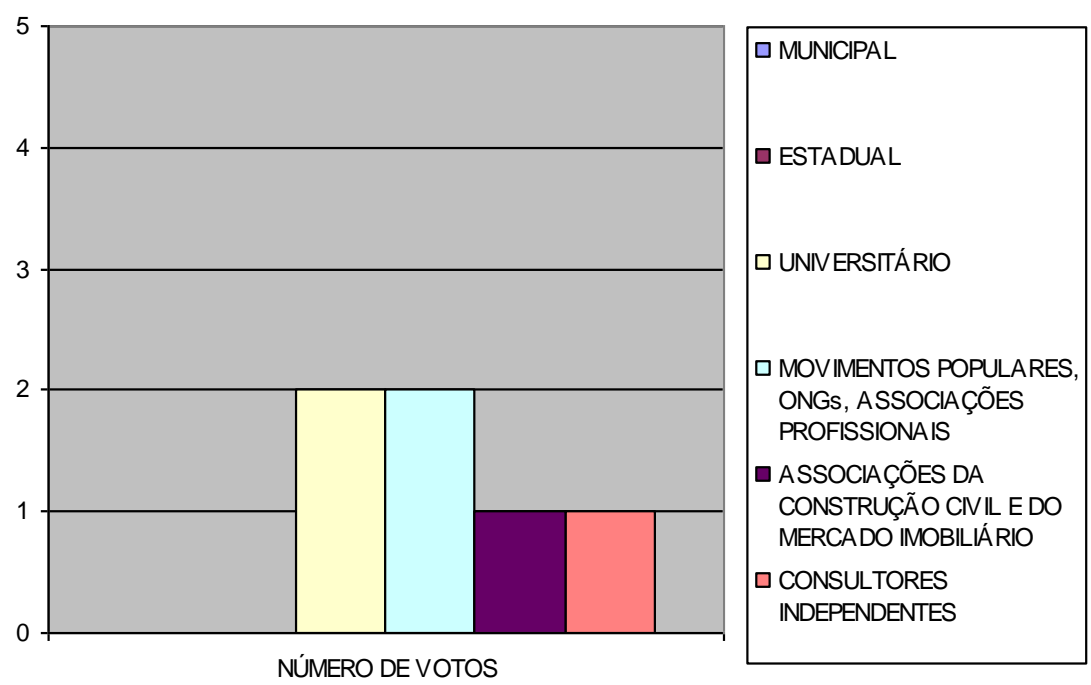

Figura 9 - Setores dos especialistas que estão pessimistas em relação à aplicação do Estatuto da Cidade em Salvador. Fonte: Pesquisa Especialistas e Estatuto da Cidade em Salvador-Bahia, Novembro/2010. Nota: Elaboração da autora. 
Figura 10

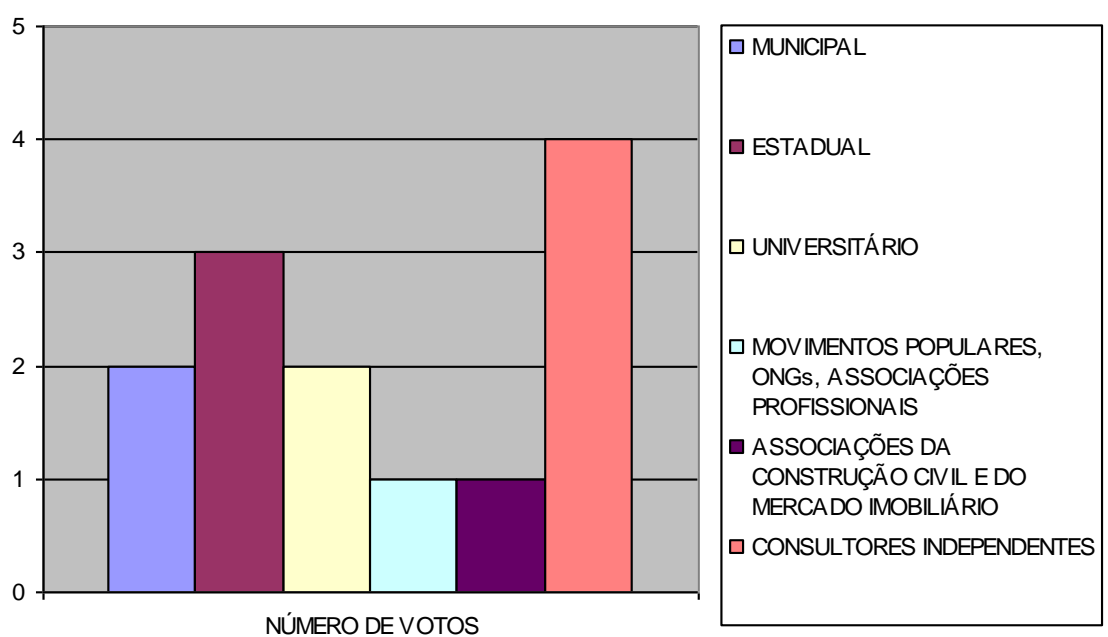

Figura 10 - Figura 10 - Setores dos especialistas que estão cautelosos em relação à aplicação do Estatuto da Cidade em Salvador. Fonte: Pesquisa Especialistas e Estatuto da Cidade em Salvador-Bahia, Novembro/2010. Nota: Elaboração da autora.

Os otimistas apontam para os ganhos já obtidos por meio da regularização fundiária, da prática das audiências públicas, dos debates e dos fóruns que, de qualquer modo, estão estimulando a reflexão e a discussão pública dos problemas de Salvador; para os pessimistas a situação de Salvador é crítica e a aplicação do EC é uma tarefa impossível dado o nível de comprometimento da gestão municipal; finalmente os mais cautelosos consideraram que o desafio é imenso, mas pode ser vencido se os instrumentos do EC forem aplicados de acordo com os objetivos do EC, ou seja, com o restabelecimento da prioridade do interesse público sobre o privado.

O segundo bloco do questionário compõe-se por questões mais subjetivas e avaliações mais qualitativas cujas respostas contavam com listagens de itens pré-definidos. No que concerne aos temas do PDDU 2007 que apresentam as maiores dificuldades para a aplicação efetiva do EC, visando à melhoria das condições urbanas de Salvador, os especialistas elegeram o ordenamento territorial e o desenvolvimento político e institucional como os temas relativamente aos quais se apresentam os maiores obstáculos para uma aplicação efetiva do EC. Os temas foram propostos no corpo do questionário e os especialistas votavam naqueles que julgassem encerrar o maior grau de dificuldade em termos de uma aplicação prática da lei. Os especialistas podiam votar em, no mínimo dois e no máximo quatro temas pela ordem, partindo do que apresenta mais dificuldades. A escala horizontal representa o número absoluto de votos que cada um dos temas recebeu dos especialistas (Figura 11). 


\section{Figura 11}

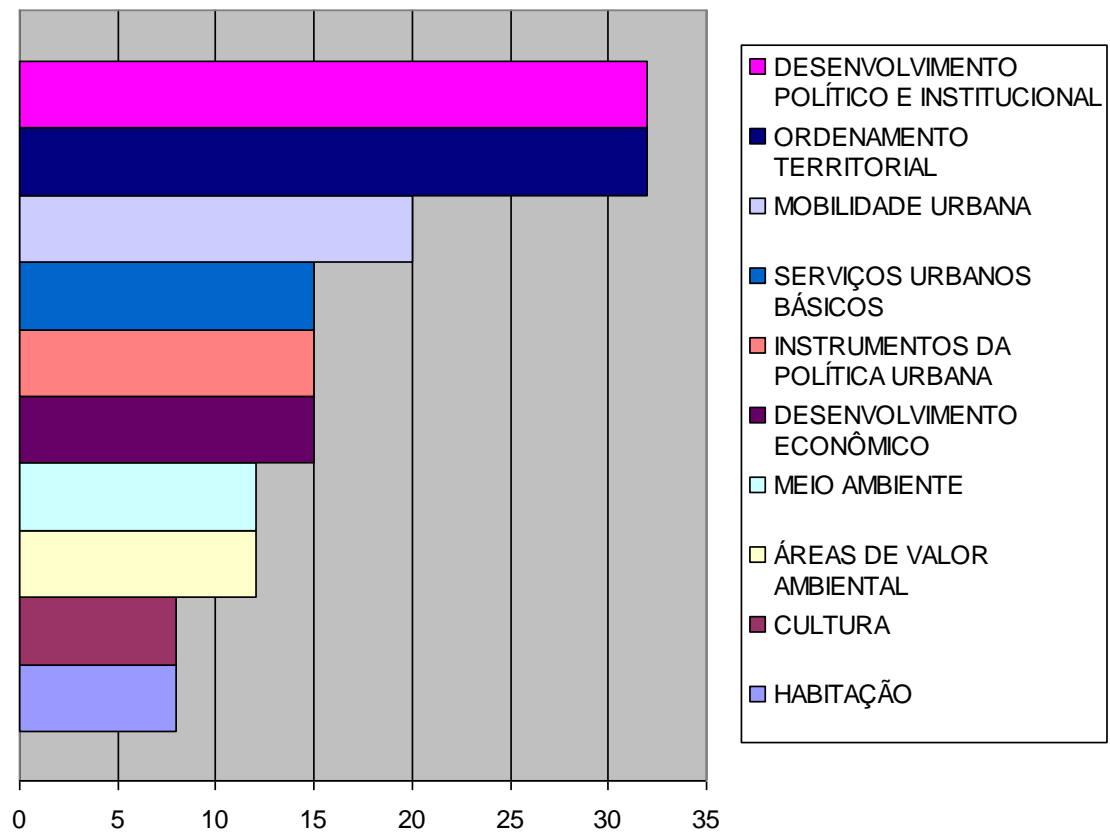

Figura 11 - Temas eleitos pelos especialistas como sendo os que apresentam as maiores dificuldades para a aplicação efetiva do Estatuto da Cidade em Salvador. Fonte: Pesquisa Especialistas e Estatuto da Cidade em Salvador-Bahia, Novembro/2010. Nota: Elaboração da autora.

Embora tenha ocorrido um empate entre os dois temas considerados mais "problemáticos", em termos da aplicação do EC, a participação dos setores na composição dos votos foi diferenciada. A escala gráfica vertical representa o número de votos obtidos, nos grupos de setores, pelos três temas que apresentam, segundo os especialistas ouvidos, as maiores dificuldades para a aplicação do EC (Figura 12). 


\section{Figura 12}
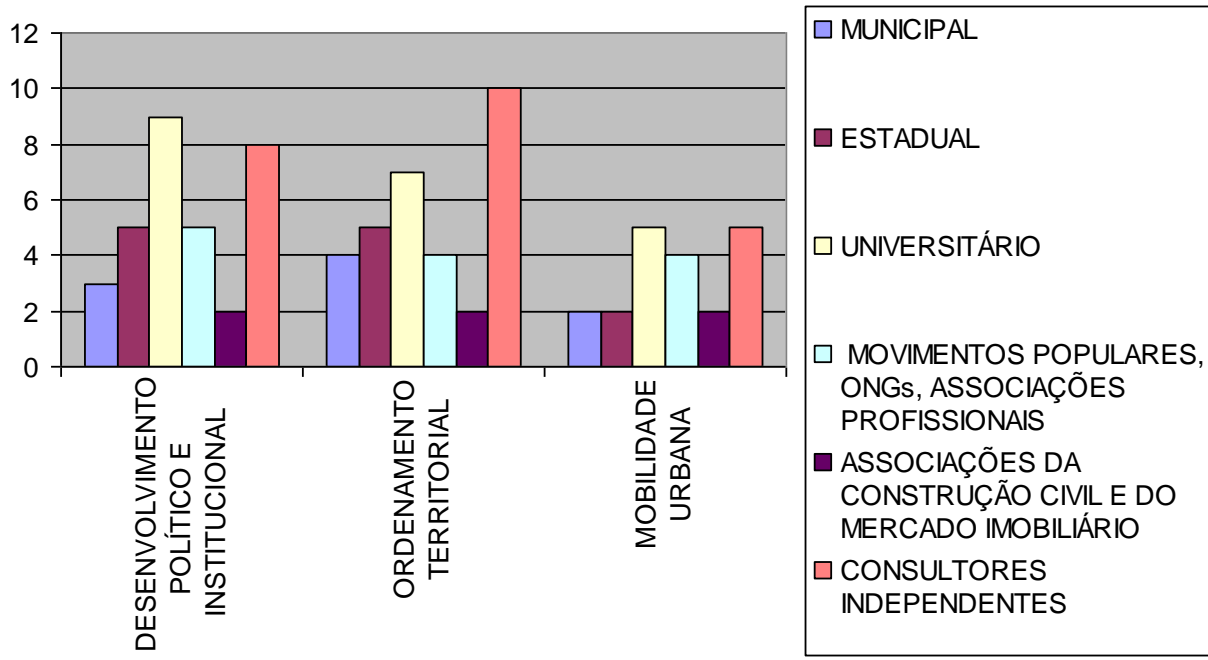

Figura 12 - Contribuição dos setores na votação dos 3 temas que apresentam as maiores dificuldades para a aplicação efetiva do Estatuto da Cidade em Salvador. Fonte: Pesquisa Especialistas e Estatuto da Cidade em Salvador-Bahia, Novembro/2010. Nota: Elaboração da autora.

O desenvolvimento político institucional teve uma maior contribuição dos especialistas do setor universitário, seguido pelo dos consultores e, de forma inversa, o ordenamento territorial obteve mais atenção do setor de consultores seguido pelo universitário; a mobilidade urbana recebeu igual contribuição destes dois setores, seguidos pelos movimentos populares e associações de classe.

Os especialistas que votaram de maneira mais uniforme dentro do segmento foram aqueles do setor estadual e das associações de empresas da construção civil e imobiliárias, mostrando mais homogeneidade de opinião no grupo. O setor que apresentou maior variação foi o dos consultores, mostrando alguma heterogeneidade dentro do grupo.

No que se refere aos problemas passíveis de ser controlados ou minimizados por meio do uso de instrumentos de regulação urbanística constantes do EC, foram aceitos em bloco os seguintes: aproveitamento de vazios urbanos, especulação imobiliária, regularização fundiária e urbanização de favelas, ainda que este último fosse ligeiramente mais votado. Vale lembrar que é praticamente impossível, em Salvador, o aproveitamento de vazios, já que a cidade não dispõe mais de porção relevante de terras não ocupadas.

Dos instrumentos de regulação urbanística preconizados pelo Estatuto da Cidade, o que teve ou tem importância prática especial para Salvador, na opinião da maior parte dos especialistas, é a Transferência do Direito de Construir (TRANSCON). Entretanto, observou-se que as práticas atuais envolvendo este instrumento têm sido contrárias aos propósitos do EC. Chamou-se atenção 
para o fato de que muitos instrumentos ainda necessitam de regulamentação para que possam ser executados, na prática, e produzir efeitos na cidade.

Todavia, a exigência do Estudo de Impacto de Vizinhança (EIV), embora não regulamentado, gerou a necessidade de sua realização por iniciativa do Ministério Público Estadual para o caso do empreendimento do Horto Bela Vista, no bairro do Cabula. Tal fato evidencia a importância do instrumento na rotina do rito processual para concessão do Alvará de Licença para Edificação, mas ainda ignorado pela Prefeitura. Espera-se que a popularização do EIV alerte os empreendedores sobre os impactos ambientais para além da edificação de um empreendimento ou das divisas de um lote ou gleba.

Em relação aos principais limitadores para que o Estatuto da Cidade se torne uma lei efetiva de desenvolvimento urbano em Salvador foram apontadas diversas questões com amplitudes variadas. Os especialistas ligados ao desenvolvimento econômico tenderam a analisar a questão de uma perspectiva mais ampla e com um enfoque social e político; para eles as limitações à aplicação do EC começam por imposição do próprio modo de produção capitalista, dentro do qual se torna muito difícil impor condições aos empresários urbanos por meio de legislação. Sob esse enfoque, o problema começaria pela própria crença de que tais legislações podem ser aplicadas com tal grau de imposição, para a realidade brasileira. Considerou-se que é preciso tomar outras providências para que O EC funcione adequadamente. Segundo um especialista do setor estadual, os regulamentos, às vezes, funcionam ao contrário ou como fachadas para dissimular a má qualidade de alguns projetos ou propostas apresentadas.

Ainda do ponto de vista político, para uma aplicação efetiva do EC, os profissionais de todos os setores apontaram para a necessidade de uma completa remodelação da sociedade, em que o assunto do planejamento urbano seja tratado como uma questão de cidadania, de fortalecimento das instituições, de cobrança e monitoramento dos gestores públicos e não somente como uma questão técnica.

Embora as questões mais amplas relacionadas ao aperfeiçoamento político e institucional, dentro do capitalismo, tenham sido preponderantes nas respostas, alguns especialistas foram mais diretos apontando as seguintes dificuldades específicas: a ação de bastidores do setor imobiliário; a ausência de controle social; a má qualidade do debate dos movimentos sociais que gera apenas as necessárias reivindicações pontuais de sempre sem uma preocupação de se compreender as questões coletivas; a tradição tecnoburocrática e autoritária dos gestores públicos municipais (funcionários de carreira, agentes políticos, funcionários comissionados etc.); a inexistência de infraestrutura de planejamento na Prefeitura Municipal e, principalmente, uma falha do próprio EC, qual seja, a inexistência de uma abordagem metropolitana. Sem essa dimensão, considera-se 
impossível planejar uma cidade como Salvador, pois seus problemas, como das demais grandes cidades, ultrapassam seus limites políticos e administrativos.

No dizer dos especialistas do setor ambiental algumas especificidades de Salvador contribuem apenas para reduzir as possibilidades de aplicação do EC, a exemplo da escassez de áreas na zona urbana, das imensas desigualdades sociais e econômicas existentes, da cultura da indiferença local em relação às questões urbanísticas e das dificuldades financeiras do Município.

Em seus comentários, os profissionais deste setor destacaram a atuação dos movimentos sociais por meio do Fórum A Cidade Também é Nossa que move uma Ação Civil Publica juntamente com entidades como o Instituto dos Arquitetos do Brasil na Bahia (IAB-BA), o Conselho Regional de Engenharia e Arquitetura da Bahia (CREA-BA), a Associação Baiana de Imprensa (ABI), o Grupo de Recomposição Ambiental (Gérmen), o Grupo Ambientalista da Bahia (Gamba) e outros, que pode conduzir a um Termo de Ajustamento de Conduta (TAC).

De maneira contrária, os profissionais da construção civil e das empresas imobiliárias consideraram as especificidades de Salvador vantajosas pela diversidade da paisagem, que exige soluções arquitetônicas e urbanísticas diferenciadas, bem como pelo potencial daqueles que ainda não tem acesso a imóveis no mercado formal. Para eles, estes aspectos são fundamentais para o desenvolvimento da cidade e a legislação urbanística não deve funcionar como uma "camisa de força".

Observaram-se nesta pesquisa, raros relatos dos especialistas no que se refere às suas experiências profissionais com a aplicação de instrumentos do EC. De um modo geral, as experiências se restringiram à realização de planos diretores, à prestação de consultorias de planejamento urbano em geral e para EIV, e para a elaboração da legislação municipal de uso e ocupação do solo.

O resultado geral da pesquisa revelou que a maior parte dos especialistas, não importando o setor nem mesmo a especialidade, deu ênfase na questão do desenvolvimento político e institucional, como condição essencial para que um discurso que tem por base um ideário social e valores coletivos, como é o caso do EC, se torne uma realidade em Salvador. Os resultados sugerem também que a discussão dos problemas urbanos envolve fatores importantes como os culturais e educacionais para romper com a "indiferença" da população no que se refere ao espaço coletivo urbano

No que diz respeito à diferença de opinião relativa, entre os setores ou segmentos de opinião, observou-se que os setores mais críticos e, consequentemente os mais pessimistas em relação a uma aplicação efetiva do EC em Salvador, são os setores universitário, dos consultores independentes e das organizações não governamentais e de classe. Esses setores são aqueles cujo 
posicionamento tem buscado privilegiar as questões coletivas, em lugar das individuais ou de pequenos grupos; seu olhar para a cidade, portanto, tem uma perspectiva mais ampla e de mais longo prazo. Parece haver, em Salvador, um antagonismo de opinião entre estes e o setor empresarial. Apesar da perspectiva deste último ser menos ampla e de prazo mais curto, não se posiciona contra a aplicação do EC em Salvador, mas em favor de uma aplicação que não impeça o livre empreendimento e o desenvolvimento econômico da cidade, para o qual considera imprescindível a flexibilização da legislação urbanística. O que chama a atenção é o desconhecimento da lei por parte de profissionais que atuam neste setor.

Finalmente, os setores públicos, qual sejam, o municipal e estadual, de modo inverso, mostram bom domínio dos conteúdos teóricos do EC, mas estão bastante pessimistas em relação sua aplicação por considerar que o problema está no campo político, no qual os técnicos têm pouco poder de interferência.

\section{CONCLUSÃO}

O descontentamento geral é a marca do processo de planejamento urbano de Salvador. Esse resultado foi verificado por ocasião do tumultuado processo de discussão e aprovação dos PDDU's de Salvador, tanto em 2004 quanto e 2007, quando os planos adotaram os paradigmas do EC. As dificuldades nascem, basicamente, de um desequilíbrio do jogo de forças entre interesses coletivos e interesses privados. De um lado, os setores da construção civil e imobiliário, pressionam a legislação urbanística pela liberação de áreas, gabaritos e índices de aproveitamento de terrenos; de outro, as organizações ambientais, de classe e as associações de moradores, por meio do Ministério Público, tentam conter a especulação e garantir o direito à cidade.

Nesse cenário, as diretrizes e os objetivos originais dos instrumentos urbanísticos postulados pelo Estatuto da Cidade, para o caso de Salvador, estão comprometidos, pois o peso dos atores sociais e agentes econômicos, envolvidos no sistema de decisões negociadas, é bastante diferenciado. O poder municipal não age como um verdadeiro mediador do conflito, optando por converter-se em refém dos setores da construção civil e imobiliário, os quais dominam segmentos econômicos que geram arrecadação, exigindo, em troca, flexibilizações da legislação urbanística.

Na prática evidencia-se que os setores populares, os menos influentes e o espaço público coletivo não são os grandes beneficiários da era do Estatuto da Cidade; uma década após a sua aprovação, as transformações ocorridas em Salvador não qualificam esses setores. A pesquisa qualitativa empreendida neste trabalho corroborou esta contradição, para a qual já apontavam alguns registros e dados quantitativos. Na opinião dos profissionais de seis setores da cidade, 
ligados ao planejamento regional e urbano, a aplicação de certos instrumentos urbanísticos só tem eficácia quando se trata de proporcionar benefícios para o empresariado, notadamente os da construção civil e imobiliário, e que, contrariamente aos princípios do EC, a aplicação de tais instrumentos inexiste quando lhes é inconveniente.

Há sérios indícios de que o modo como os setores da construção civil e imobiliário se apropriam dos planos diretores de desenvolvimento urbano e o uso que fazem de instrumentos como a TRANSCON e as parcerias público-privadas, serve para aumentar a sua lucratividade. As chamadas contrapartidas sociais, requeridas pela aplicação de tais instrumentos para munir o setor público com recursos que ampliam sua capacidade de ação e intervenção urbanas, não funcionam e tornaram-se letra morta para efeito do Estatuto da Cidade em Salvador.

$\mathrm{Na}$ ausência de regulamentação e de ferramentas modernas de informações georeferenciadas, em permanente atualização e acessíveis aos cidadãos, o uso de instrumentos urbanísticos têm representado mais uma forma de desvio de recursos públicos e incentivo à corrupção do que um meio de corrigir ou coibir efeitos negativos da especulação imobiliária na gestão urbana.

No início do século XXI, enquanto os negócios imobiliários florescem e se expandem na cidade de Salvador, em uma velocidade talvez nunca vista, as soluções para os chamados "problemas" urbanos permanecem no papel. Uma parte das ideias do PDDU 2007 e, provavelmente, as formulações do Estatuto da Cidade que Ihe inspiraram, perdem força em relação aos seus objetivos originais. O plano expira e vai se tornando mais um projeto utópico destinado a figurar nas estantes das bibliotecas das universidades, para seguir encantando estudantes e intelectuais como a vanguarda do chamado "pensamento urbanístico brasileiro", mas sem nenhum resultado na cidade real.

\section{REFERÊNCIAS}

BOAVENTURA, E. M. Metodologia da pesquisa: monografia, dissertação, tese. São Paulo: Atlas, 2007. $160 \mathrm{p}$.

BRASIL. Ministério das Cidades. Mobilização social e do Ministério Público Estadual da Bahia reivindicando Participação Popular no Plano Diretor de Desenvolvimento Urbano-PDDU 2002 Salvador/Ba. [Brasília], 2010. Banco de Experiências de Planos Diretores Participativos. Disponível em: http://www.cidades.gov.br/secretarias-nacionais/programas-urbanos/programas/programade-fortalecimento-da-gestao-municipal-urbana/banco-de-experiencias/bahia/salvador/ Estadual\%20da\%20Bahia\%20reivindicando\%20participacao\%20popular\%20no\%20Plano\%20Diretor \%20de\%20Desenvolvimento\%20Urbano_PDDU\%202002_Salvador_BA.pdf. Acesso em: 18 jul. 2010. 
CYMBALISTA, Renato. Estatuto da cidade: guia para implementação pelos municípios e cidadãos. São Paulo: Instituto Polis; Caixa Econômica Federal, 2002. 273 p.

CONSELHO REGIONAL DE ENGENHARIA, ARQUITETURA E AGRONOMIA DA BAHIA. Análise do Projeto de Lei n. ${ }^{\circ} 216 / 2007$ - Plano Diretor de Desenvolvimento Urbano do Município de Salvador - PDDU. Parecer. Salvador: CREA-BA, 2007.

Disponível em:

http://www.creaba.org.br/Imagens/FCKimagens/122009/Parecer\%20sobre\%20PDDU\%20de\%20Sal vador\%20_agosto_2007(1).pdf. Acesso em: 18 jul. 2010.

FERNANDES, Ana. Salvador, PDDU 2008: Agonia do Espaço Público. Terra Magazine, Salvador, 25 mar. 2008. Disponível em: http://terramagazine.terra.com.br/interna/0, OI2705302-El6578,00.html

JUSTIÇA embarga obras do Aeroclube. Justiça Federal Hoje, Salvador, n. 2.637, 22 jan. 2008. Disponível em: http://www.ba.trf1.gov.br/JFBA/Noticias/jfh/08-01-22.pdf. Acesso em: 14 ago. 2010.

MARICATO, Ermínia. As ideias fora do lugar e o lugar fora das ideias: planejamento urbano no Brasil. In: MARICATO, Ermínia; ARANTES, Otília; VAINER, Carlos. A cidade do pensamento único. 5. ed. Rio de Janeiro: Vozes, 2009.

MINAYO, Maria Cecília de Souza (Org.). Pesquisa social: teoria, método e criatividade. 6. ed. Petrópolis: Vozes, 1996. O QUE é PDDU? Conheça pontos positivos e negativos do Projeto. A Tarde On Line, Salvador, 25 dez. 2007. Disponível em:

http://www.atarde.com.br/cidades/noticia.jsf?id=818470. Acesso em: 18 jul. 2010.

PENTEADO, Paulo de Arruda Filho. Planejamento urbano em Salvador. Veracidade. Revista do Centro de Planejamento Municipal, Salvador, v. 1, n. 2, p. 5-11 out./nov. 1991. Disponível em: http://www.moodle.ufba.br/mod/data/view.php?d=1\&advanced=0\&paging=\&page=11. Acesso em: 18 jul. 2010.

POSTIGO critica postura da Prefeitura nos acordos com o Iguatemi. Bahia Já, 5 abr. 2008. Disponível em: http://www.bahiaja.com.br/noticia.php?idNoticia=7507. Acesso em: 14 ago. 2010.

ROCHA, Vitor. Ex-secretária denuncia esquema na prefeitura. A Tarde On Line, Salvador, 14 ago. 2010. Disponível em: http://www.atarde.com.br/cidades/noticia.jsf?id=5605731. Acesso em: 14 ago. 2010.

SALVADOR. Secretaria de Comunicação. João Henrique apresenta o PDDU aos empresários. Salvador: $\quad 2007 . \quad$ SECOM, Disponível em: http://www.comunicacao.salvador.ba.gov.br/index.php?option=com_content\&task=view\&id=1406 \&ltemid=42. Acesso em: 18 jul. 2010.

SINDICATO DA INDÚSTRIA DA CONSTRUÇÃO CIVIL DO ESTADO DA BAHIA. Desempenho do mercado imobiliário da Bahia (ADEMI-BA). Salvador: SINDUSCON: 2008. Disponível em: http://www.sinduscon-ba.com.br/indices-macroeconomicos/. Acesso em: 16 ago. 2010.

SINDICATO DA INDÚSTRIA DA CONSTRUÇÃO CIVIL DO ESTADO DA BAHIA. Emissão de alvarás (SUCOM) Salvador. Salvador: SINDUSCON, 2008. Disponível em: http://www.sindusconba.com.br/indices-macroeconomicos/. Acesso em: 16 ago. 2010. 
TEIXEIRA, Fernando. Plano Diretor de Desenvolvimento Urbano do Município do Salvador PDDU/2006: estrutura e conteúdos da minuta da lei. Veracidade. Revista da Secretaria Municipal de Planejamento, Urbanismo e Meio Ambiente, Salvador, v. 1, n. 1, dez. 2006. Disponível em: http://www.veracidade.salvador.ba.gov.br/v1/index.php?option=com_content\&view=article\&id=17 \&ltemid=3. Acesso em: 18 jul. 2010.

Trabalho enviado em 01 de outubro de 2014.

Aceito em 05 de dezembro de 2014. 